\title{
DOES PERCEPTION OF HOSPITALITY EMPLOYMENT CHANGE POST INTERNSHIP?
}

\author{
Melody E. Appietu ${ }^{1 *}$, Vincent K. Asimah ${ }^{1}$, Christopher Mensah ${ }^{1}$
}

\begin{abstract}
Remarkably, exposures to hospitality workplaces through internships have been found to rather dissuade students from envisaging hospitality career. However, knowledge of this phenomenon remains inconclusive. Consequently, this study explored the effect of internship work experience on undergraduate students' commitment and perception of the nature of hospitality work using before-and-after design. A convenience sample of 171 hospitality management students in a Ghanaian technical university completed paperand-pencil questionnaires, and data were analyzed using descriptive statistics and Wilcoxon signed-rank test. The majority of the students indicated positive perceptions of hospitality employment and were accordingly willing to work in hospitality-related jobs after graduation. Contrary to the commonly held view, commitment, attitude, and perceptions of hospitality work do not undergo significant reconsiderations post-internships.
\end{abstract}

Key Words: Hospitality internship; students' perceptions; hospitality career; work intention.

\section{INTRODUCTION}

The hospitality and tourism industry remains one of the world's largest economic sectors and continues to create jobs as well as drive exports across the globe. In Ghana, the sector generated approximately 682,000 jobs and contributed a total of USD 2,864.1 million (6.2\%) to the country's gross domestic product (GDP) in 2017 (World Travel and Tourism Council [WTTC], 2018). In tandem with the rapidly expanding hospitality and tourism industry, there has been a worldwide explosion in hospitality and tourism higher education programmes (Airey, Tribe, Benckendorff, \& Xiao, 2015), with the integration of supervised internship programmes aimed at equipping potential employees with hands-on skills and competencies needed in the industry. In spite of the expansion in the provision of hospitality higher education, the industry, compared with others across the globe, is challenged with recruiting and retaining high quality and competent workforce (Yang \& Cherry, 2008) to adequately address the growing human resources needs of the industry.

University internship programmes remain the platform for employers to identify

Melody E. Appietu 1*, Vincent K. Asimah1, Christopher Mensah 1 Department of Hospitality and Tourism Management, Ho Technical University

Email: mappietu@htu.edu.gh and recruit potential employees who express great interest in the industry as well as provide an opportunity for participants to experience the reality in the industry, thereby making informed decisions regarding their career. Although not easily defined due to its varied scope (Kim \& Park, 2013; Ruhanen, Robinson, \& Breakey, 2013), internship is defined as "a structured and career-relevant supervised professional work/ learning experience, paid or unpaid, within an approved hospitality organization, under the direct supervision of at least one practicing hospitality professional and one faculty member for which a hospitality student may or may not earn an academic credit" (Zopiatis, 2007, p.11). As practiced elsewhere, a major requirement for the award of a degree is for students to complete an internship programme in a private or public institution, working at least 400 hours in one year or less (Horng, 2004; Horng \& Lee, 2005). Internship placements are either arranged by schools or by the students. In the case of the hospitality industry, interns are mostly placed in the front-of-the-house, doing jobs such as housekeeping, food and beverage service, or food production. Duration of internships vary across universities. For example, tertiary institutions in Ghana usually schedule internship programmes during the second semester of an academic year covering a period of not less than 10 weeks. Vocational colleges, on the other hand, tend to 
sandwich the internship between two periods of academic study for a duration of six months to one year (Lee \& Chao, 2008) where students, upon completion, receive a maximum of ten to sixteen credits.

The benefits of internship to students, education institutions, and industry are adequately documented (Ayres, 2006; Kusluvan \& Kusluvan, 2000; O'Mahony, McWilliams, \& Whitelaw, 2001). However, whereas welleducated, trained, enthusiastic, and committed workforce from the tertiary levels are a desirable source of employees and vital to the success of firms in the hospitality industry $(\mathrm{Ng} \&$ Burke, 2006; Penny \& Frances, 2011), issues of hospitality workplace students developing cold feet towards hospitality careers after undertaking internship exist (Busby, 2003; Jenkins, 2001). Clearly, it appears that the exposure of students to the inner working of hospitality and tourism workplaces through the internship experience rather discourages students from seeking hospitality work after completion of their programmes of study rather than encouraging them to pursue employment opportunities in the industry (Chang \& Tse, 2015; Koc, Yumusak, Ulukoy, Kilic, \& Toptas, 2014; Lu \& Adler, 2009).

A careful review of extant literature suggests that studies have been conducted to explore the perceptions of students about the hospitality and tourism employment using different approaches, and results from these studies are inconclusive. For example, in a study conducted by Roney and Öztin (2007), students' perceptions with respect to the tourism and hospitality employment were neither favourable nor unfavourable. On the contrary, $\mathrm{Lu}$ and Adler (2009) reported favourable perception of the industry among their respondents who were interested in pursuing a career in the hospitality and tourism industry after graduation. Another study conducted by Richardson (2010) to examine the perception and attitudes of undergraduate students towards a career in tourism and hospitality using nine different dimensions also reported both negative and positive perceptions of the hospitality and tourism employment among his respondents considering the various dimensions of hospitality and tourism employment measured.

While these perceptions, to a large extent, hinder the recruitment and retention of quality staff in the industry globally, it appears that there is relatively little evidence of empirical studies conducted in this area among hospitality and tourism students in tertiary institutions and, more specifically, from a developing country's (Ghanaian) perspective. This study seeks to find out whether the perceptions of students of hospitality and tourism management in a Ghanaian Technical University about hospitality employment changes post internship. The study adopts a pre- and post-internship experience approach, focusing on four major dimensions, namely nature of hospitality work, commitment towards the industry, perceived social status of hospitality, and perceived industry-person fit/ congeniality.

\section{LITERATURE REVIEW}

\section{Theoretical Framework}

The social cognitive career theory (SCCT) by Lent, Brown, and Hackett (1994, 1996) is adopted for this study. Social cognitive career theory is anchored in Bandura's social cognitive theory and generally focuses on several cognitive-person variables (self-efficacy, out-come expectations, and goals) and how these variables interact with other aspects of the person and his/her environment (gender, ethnicity, social supports, and barriers) to help shape the course of career development. SCCT has been studied widely among science, technology, engineering, and math students to analyse their vocational study in reflection to their career development (Atadero, Rambo-Hernandez, \& Balgopal, 2015; Lent, Brown, \& Hackett, 2000; Lent et al., 2003, 2008; Mueller, Hall, \& Miro, 2015).

According to SCCT, career development is influenced by both objective and perceived environmental factors. The objective factors include the quality of the educational experiences to which one has been exposed and the financial support available to one for pursuing particular career options. This theory is relevant to the study of students' career choice in hospitality employment after their exposure to industrial internships. Within the hospitality context, the theory has been applied together with internship, mediating its impact on career development of students (Sabirin, Munawaroh, \& La Are, 2018). The thrust of the model is situated within the context of the former objective factor where the quality of educational experiences to which students are exposed to potently influences 
their perception of developing a career in the hospitality industry. Given that job-related experience during internship constitutes a holistic educational experience providing potential employees with personal experience and opening opportunities to apply knowledge at work, improving job knowledge, and crystalizing work values, the quality of internship as an educational experience cannot be compromised.

\section{Hospitality Work Experience and its Influence on Career Choices}

A number of studies have explored the influences of both structured and unstructured work on career choices of potential employees (Bosselman, 2014; Brown, Arendt, Jiang, \& Tribe, 2009; Richardson, 2012; Wan et al., 2014). Others have also examined how internship experiences particularly affect career choices of interns (Chen \& Shen, 2012; Kim \& Park, 2013). Similarly, as part of wider research projects, some studies have also touched on internships and career choices following internship experiences (Hsu, 2013; Zopiatis \& Theocharous, 2013). In the meantime, limited studies have also examined how higher education internship or work experiences of hospitality and tourism interns affect their future career intentions (Robinson, Ruhanen, \& Breakey, 2016). With the industry experiencing challenges with the attraction, recruitment, and retention of quality employees (Lee \& Chao, 2013; Soliman, 2011), it becomes necessary to understand the perception of hospitality students regarding hospitality jobs in terms of their commitment to the industry, the social status of hospitality employment, industryperson congeniality, as well as their perceptions of the nature of hospitality work prior to their internships and their perceptions after their internship experiences. This approach remains relevant, as it clearly exposes the direct impact of internship experiences on the students' future engagements with the industry.

Riley, Ladkin, and Szivas (2002) aver that the image of the hospitality and tourism industry seems to have two sides. On one hand, the industry is seen as a glamorous, attractive, and exciting one, while, on the other hand, it is deemed as struggling with a wide variety of difficulties (i.e. low skills, low status, and low pay etc.). With respect to the latter perception, it is obvious that the sector has a particularly poor image in the eyes of potential employees, which suggests the greater difficulty in attracting, recruiting, and retaining quality staff (Aksu \& Koksal, 2005; Brien, 2004; Jenkins, 2001; Kusluvan \& Kusluvan, 2000). Some researchers (Doherty et al., 2001; Jenkins, 2001) have reported a higher number of hospitality and tourism management graduates leaving the industry or even failing to enter the industry upon graduation due to issues such as low job satisfaction, the nature of the hospitality employment, poor employment conditions, social status, industry-person congeniality, and absence of motivating factors, resulting in high staff turnover and wastage of trained and experienced personnel. Thus, the proportion of workers with tertiary qualifications is much lower, compared to sectors of other industries (Australian Bureau of Statistics, 2006), and yet there are higher numbers of enrollment on the programme across the universities globally.

The desire for satisfied hospitality students to join the industry after graduation is one major benefit derived from a hospitality internship programme. In the hospitality and tourism management education, a supervised industrial internship is often regarded as an absolute necessity and, therefore, incorporated in most hospitality programmes offered in higher education institutions. This concept has been embraced by all relevant stakeholders (i.e., students, academic institutions, and the hospitality organization) due to the enormous benefits it provides. Fundamentally, the hospitality internship programme is a helpful step in preparing students for the industry by giving them an opportunity to understand working conditions, develop relationships with hospitality workers and supervisors (Marinakou \& Giousmpsoglou, 2013), and more importantly, improve students' future employment prospects by helping to better manage their expectations (Busby, 2003; Chen \& Shen, 2012; Kim \& Park, 2013; Lee \& Chao, 2013; Zopiatis \& Theocharous, 2013) as well as gain insights into the career opportunities that the industry offers (Chen \& Shen, 2012; Kim \& Park, 2013; Lee \& Chao, 2013; Richardson, 2012; Tse, 2010; Zopiatis, 2007; Zopiatis \& Theocharous, 2013). Consequently, there is a vast improvement in students' ability and competence to work with people, their knowledge on how the hospitality industry works, their ability to adapt to changes, 
and their leadership and financial management competence after the supervised internship experience (Lam \& Ching, 2007).

Hospitality undergraduates have, over the years, viewed their pre-work experience in the industry as the main reason for their postinternship career decisions where they lack confidence about their future in the industry after their internships (Wu \& Wu, 2006). Kusluvan and Kusluvan (2000) developed a multidimensional attitude scale to investigate students' career perceptions of hospitality employment, which was validated using fourth year tourism and hotel management students in Turkey. Results from their study indicated that students held negative perceptions towards almost all dimensions of working in hospitality. Further, the attitudinal scale was used in an Australian context by Richardson (2010a) and the results showed that more than $50 \%$ of the respondents surveyed were contemplating careers outside the industry, with $92 \%$ of these respondents citing that such a decision primarily resulted from negative working experiences in the industry. Significantly, there was a discrepancy between students' pre-internship expectations and their post-internship satisfaction (Cho, 2006). Similarly, Leslie and Richardson (2000) observed discrepancies between tourism students' perceptions of pre-work experience and their actual experience. Hospitality students subsequently became considerably less interested in selecting hospitality as their first career choice after gaining internship experience while others left the industry because of unfulfilled expectations (Jenkins, 2001; Kim \& Park, 2013; Kusluvan \& Kusluvan, 2000; Raybould \& Wilkins, 2005; Richardson, 2009).

\section{Perceptions on the Dimensions of Hospitality Employment}

Throughout the literature, studies exploring the perception of students regarding the hospitality employment have related factors such as the nature of the hospitality work, social status, industry-person congeniality, and commitment to the industry among others. The nature of the hospitality work is described as complex due to rigid work shift, long and irregular working hours and days resulting in difficulty to establish a balance in work and family life (Wan, Wong, \& Kong, 2014), low wages (Poulston, 2008), and the lack of employee training (Davidson,
Timo, \& Wang, 2010). While this is the case, results from a study conducted by Richardson (2010) to explore Generation Y's perceptions and attitudes towards careers in hospitality and tourism in Australia corroborated these facts, as more than half of the respondents surveyed perceived the industry to be stressful, had too long working hours which are unsuitable for one to lead a normal life, and negatively affects family life. Similarly, Aloudat (2017), in a study among undergraduate students' perceptions of a tour guiding career in Jordan, reported that a high percentage of the respondents believed it is difficult to have a stable income working as a tour guide, tour guiding involves long working hours, and is very stressful. Despite these negative perceptions respondents had regarding hospitality and tourism employment, positive perceptions were reported by Richardson (2008, 2010) and Aloudat (2017), where the majority of respondents found working in the industry very interesting $(85.5 \%)$ while indicating that there was always something new to learn.

As expressed by Kusluvan and Kusluvan (2000), an important element that influences the attitude, career plans, and employment aspirations in hospitality and tourism is industry-person congeniality. Industry-person congeniality is very important particularly in the tourism and hospitality industry due to its characteristic of inseparability. Most of the services in the sector are based on human performance and, therefore, services are produced and consumed by the customer at the same time. Industry-person congeniality is defined by the fact that individuals' confidence, personality, and character are closely related with the type of jobs available in the industry. In addition, industry-person congeniality comprises the confidence an individual possesses when he/ she gets the opportunity to use his/her

skills and abilities to work in the industry, which results in seeing satisfied customers and finding pleasure in working in the industry. Service providers have to rely heavily on the competence and ability of their employees to understand consumer requirements and react in a timely and appropriate manner (Ghobadian, Speller, \& Jones, 1994) and also respond to the emotional demands of their customers. Internship students, based on their exposure to the industry, were able to express how well they fit into the industry. According to results from Richardson 
(2010), the vast majority of respondents $(82.0 \%)$ believed that their personality and character fits well with the type of jobs available in the industry and further believed that they will get an opportunity to use their skills and abilities working in the industry $(89.1 \%)$. In addition, $87.6 \%$ of the respondents also claimed that they get pleasure out of seeing satisfied customers and also find pleasure working in the industry $(74.0 \%)$.

Investigating the perception of students regarding the social status dimension of the hospitality and tourism employment, some researchers have reported that students feel proud to talk to their families and friends about their future career and, in return, their families and friends are equally proud of their future career. They further indicated that working in tourism and hospitality industry at all levels is a beneficial and important job. These notwithstanding, hospitality students will not allow their children to pursue a career in the industry in future, as they think employees in the industry are not respected and are less valued in society (Aloudat, 2017; Richardson, 2008, 2010). Students' level of commitment to the hospitality industry explores their likelihood of pursuing a career after graduation and that will, to a large extent, be influenced by the level of internship satisfaction experienced. Indeed, one major finding from a study by Richardson (2010) indicated that respondents felt the disadvantages and negatives of the industry outweighs the advantages and positives and, therefore, expressed regret in choosing hospitality as a vocation path, stating it was a big mistake they made. Subsequently, respondents in his study claimed they will not encourage their children, family, and friends to pursue a career in the industry. Further, respondents claimed they preferred to work in other industries rather than the hospitality industry. In effect, preinternship experiences of students influence their commitment to the industry (Kim \& Park, 2013; Richardson, 2009) in future, hence, the difficulty faced by the industry in recruiting and retaining qualified employees.

\section{METHODOLOGY}

The study population comprised 171 first and second year students studying hospitality and tourism management in a three-year higher national diploma awarding technical university in the Volta Region of Ghana. Data was collected from the same students at the pre and post internship stage in May and October, 2018 respectively by the authors. Using a convenience sampling technique, questionnaires were administered to 150 students in the university classrooms at the end of lectures, 138 of which were found usable, constituting a response rate of $90 \%$. At the post-internship data collection stage which took place in October 2018 after students had returned to school from a 10 -week industrial internship experience, 150 questionnaires were conveniently self-administered to the students in their classrooms, 103 of which were found usable, constituting 68 percent response rate. The pre and post method of data collection employed in this study provides an advantage of measuring the students' perceptions of hospitality employment before their actual exposure to the industry. It also helps to clearly explore the direct impact of the

internship experience on students' future engagement with the industry by comparing both results. At both stages of the data collection process, the same questionnaires were administered and the researchers were able to control the process because of the classroom setting. Students were also informed of their voluntary participation in the study, termination of their participation at will. We also assured them of confidentiality and anonymity.

In measuring students' perception of hospitality employment, a questionnaire was adopted from the works of Richardson (2010) and Aloudat (2017) and pre-tested for the relevance and applicability of the instrument in a Ghanaian context. This enabled a revision of the questionnaire for this study. Internal consistency of the instrument was found to be good (Cronbach's Alpha $=0.849$ ) beyond the recommended threshold ranging from 0.5 to 0.6 (Nunnally, 1978). The entire constructs studied were measured on a five-point Likert scale anchored on 5 "strongly agree," 4 "agree," 3 "neither agree nor disagree," 2 "disagree," and 1 "strongly disagree." The questionnaire was divided into two sections. Section A collected information on respondents' socio-demographic data whereas Section B measured respondents' perception of the hospitality employment, using four different dimensions i.e. commitment to the industry, nature of hospitality work, industry person congeniality, and social status. Twelve items adopted from the authors were used to 
measure students' commitment to the hospitality industry. For example, "I see myself working in the hospitality industry after graduation." Students' perception on the nature of the hospitality work was measured using seven items. An example is "Family life is greatly affected due to the nature of hospitality work." Students' industry-person congeniality as well as perceived social status was measured using eight and four items respectively. An example from both items include "I like to see satisfied customers" and "My family is proud of my future profession as a hospitality worker." Descriptive statistics were used to describe the demographic data of respondents whereas Wilcoxon signed rank test was used to examine the difference in the industry, nature of hospitality work, industryperson congeniality, and perceived social status of hospitality career. pre- and post-internship perception of respondents' commitment to the hospitality.

\section{RESULTS}

\section{Profile of Respondents}

A greater proportion of the research participants were females $(90.7 \%)$ whereas males constituted only 9.3 percent of the sample. The average age of the respondents was 24.49 (SD-4.71). The sample was overwhelmingly dominated by unmarried students while married respondents were in the minority (9.9\%). About $28.4 \%$ of the respondents were first year students while $71.6 \%$ were in the second year of schooling in the institution.

\section{Students' Perceptions of the Hospitality Employment}

This section of the study was employed to understand the students' perceptions of the different aspects of working in the hospitality industry and to further explore whether these perceptions will change post internship. The resulting highlights from the four (4) dimensions measured indicated that students had both positive and negative perceptions of hospitality employment. These perceptions, however, did not change after their internship experience and, therefore, had no influence on their future career intensions towards the industry.

\section{Commitment to the Hospitality Industry}

Most of the students saw themselves working in the hospitality industry after graduation (81.9\%) and relatedly, almost 7 out of 10 respondents indicated that they would like to work in the hospitality industry after graduation $(73.8 \%)$ to the extent that some indicated their intention

\section{Table 1: Students' Commitment to the Hospitality Industry}

\begin{tabular}{llllll}
\hline Statement & SA (\%) & N (\%) & SA (\%) & M & SD \\
\hline $\begin{array}{l}\text { Disadvantages of working in the hospitality industry outweighs its } \\
\text { advantages }\end{array}$ & 29.6 & 21.3 & 49.2 & 3.30 & 1.32 \\
I see myself working in the hospitality industry after graduation & 6.7 & 11.3 & 81.9 & 4.29 & 1.03 \\
I do not plan to work in any other industry apart from the hospitality & & & & & \\
industry & 18.8 & 15.8 & 65.4 & 3.81 & 1.34 \\
I would only work in high paid jobs & 16.6 & 19.9 & 63.5 & 3.79 & 1.16 \\
I would recommend hospitality jobs to friends and relatives & 9.5 & 9.1 & 81.3 & 4.15 & 1.06 \\
It was a big mistake to choose hospitality as a career path & 70.7 & 8.4 & 20.9 & 2.10 & 1.44 \\
I will work in the hospitality industry only if I am made a supervisor & & & & & \\
after graduation & 51.3 & 21.4 & 27.3 & 2.60 & 1.37 \\
It is definite I will not work in the hospitality industry after & & & & & \\
graduation & 47.5 & 22.3 & 30.3 & 2.62 & 1.43 \\
I would do any job in the hospitality industry after graduation & 15.0 & 18.4 & 66.7 & 3.79 & 1.18 \\
I would like to work in the hospitality industry after graduation & 14.6 & 11.6 & 73.8 & 3.97 & 1.51 \\
I would not want my child to study or work in the hospitality & & & & & \\
industry & 47.7 & 17.6 & 34.7 & 2.75 & 1.10 \\
I am happy to have chosen hospitality as a profession & 9.7 & 11.0 & 79.2 & 4.20 & 1.13 \\
& & & & & \\
\hline
\end{tabular}


not to work in any other industry apart from the hospitality industry $(65.4 \%)$. Majority of the students would recommend hospitality jobs to their friends and relatives $(81.3 \%)$. However, less than half of them indicated that they would not want their children to study or work in the hospitality industry $(47.7 \%)$. Almost half of the students (49.2\%) intimated that the disadvantages of doing hospitality work outweigh its advantages (Table 1). In spite of this assertion, about $79.2 \%$ of the respondents indicated that they were happy to have chosen hospitality as a career path (Table 1).

\section{Nature of Hospitality Work}

Findings presented in Table 2 with respect to this dimension show that students were of the view that there was something new to learn each day in hospitality jobs $(81.3 \%)$ and that they found jobs in the hospitality industry interesting $(76.5 \%)$. Notwithstanding these apparent positive views, students found jobs in the sector stressful (62.1\%) while acknowledging that hospitality work is characterized by long working hours $(59.8 \%)$. More than half of the students $(56.3 \%)$ asserted that family life is affected by the nature of hospitality work and that working hours in hospitality workplaces are unsuitable for a regular life (55.2\%).

Table 2: Students' Perception on the Nature of Hospitality Work

\begin{tabular}{|c|c|c|c|c|c|}
\hline Statement & $\mathrm{SD}(\%)$ & $\mathrm{N}(\%)$ & $\mathrm{SA}(\%)$ & M & $\mathrm{SD}$ \\
\hline I find jobs in the hospitality industry interesting & 12.6 & 10.9 & 76.5 & 4.07 & 1.19 \\
\hline Most jobs in the hospitality industry are low skilled & 54.4 & 15.9 & 29.7 & 2.55 & 1.42 \\
\hline Jobs in the hospitality industry are stressful & 20.7 & 17.2 & 62.1 & 3.62 & 1.29 \\
\hline Working hours are too long in the hospitality industry & 18.8 & 21.3 & 59.8 & 3.66 & 1.22 \\
\hline Family life is negatively affected due to the nature of the hospitality work & 24.6 & 19.2 & 56.3 & 3.48 & 1.34 \\
\hline There is always something new to learn each day in hospitality jobs & 7.9 & 10.8 & 81.3 & 4.22 & 1.04 \\
\hline Working hours are not suitable for a regular life in the hospitality industry & 20.7 & 24.1 & 55.2 & 3.51 & 1.25 \\
\hline
\end{tabular}

\section{Industry-Person Congeniality and Social Status}

A greater proportion of the students indicated that the hospitality field suited their abilities $(86.6 \%)$ and that they enjoyed doing customer service work $(85.1 \%)$, liked to serve others $(83.7 \%)$, liked to see satisfied customers $(82.8 \%)$, and get pleasure working in the

hospitality industry $(73.9 \%)$. Furthermore, students were of the opinion that they can use their skills and abilities in the hospitality industry $(77.0 \%)$ because their character fits with the industry $(73.2 \%)$. In spite of selfopinion of industry-person affinity, quite a substantial proportion of the students $(40.3 \%)$ indicated they felt like maid servants working in the hospitality industry. As regards students' perception of social status of hospitality work, a majority of the students $(78.5 \%)$ said their families are proud of their future profession as hospitality workers and were able to proudly talk to their relatives and friends about their future hospitality career. On the other hand, about 4 out of 10 students indicated that hospitality workers are undervalued (Table 3).

\section{Differences in Students' Perception on the Dimensions of Hospitality Employment}

This section of the study is relevant because it most importantly seeks to answer the main objective of the study. Students' perceptions of hospitality employment before and after their internship experiences are analyzed using Wilcoxon test to determine the direct impact of hospitality work experiences on future career intensions towards the industry.

\section{Commitment towards the Hospitality Industry}

Results of whether students' commitment towards the hospitality industry will change after internship are presented in Table 4. Out of the 12 commitment statements, none of them indicated a statistically significant difference between preinternship and post-internship perceptions. In effect, students' commitment to the hospitality industry in future was not influenced by their experiences during internship. 
Table 3: Students' Perception of Industry-Person Congeniality and Social Status of the Hospitality Industry

\begin{tabular}{llllll}
\hline Statement & $\mathrm{SD}(\%)$ & $\mathrm{N}(\%)$ & $\mathrm{SA}(\%)$ & $\mathrm{M}$ & $\mathrm{SD}$ \\
\hline Industry-person congeniality & & & & & \\
My character fits with the hospitality industry & 13.4 & 13.4 & 3.2 & 3.96 & 1.18 \\
I can use my skills and abilities in the hospitality industry & 13.6 & 9.4 & 77.0 & 4.05 & 1.21 \\
I feel like a maid servant working in the hospitality industry & 43.6 & 16.1 & 40.3 & 2.89 & 1.54 \\
I get pleasure working in the hospitality industry & 13.0 & 13.0 & 73.9 & 4.06 & 1.11 \\
I like to see satisfied customers & 10.8 & 6.5 & 82.8 & 4.26 & 1.02 \\
I like to serve others & 10.0 & 6.3 & 83.7 & 4.25 & 1.10 \\
I enjoy doing customer service work & 7.1 & 7.9 & 85.1 & 4.32 & 0.88 \\
This hospitality field suits my ability & 4.2 & 9.2 & 86.6 & 4.14 & 0.80 \\
Social status & & & & & \\
My family is proud of my profession as a hospitality worker & 11.0 & 10.5 & 78.5 & 4.12 & 1.12 \\
Working as a hospitality staff is respected & 16.0 & 14.3 & 69.3 & 3.87 & 1.24 \\
I think that those working as hospitality staff are not valued & 34.7 & 19.2 & 46.0 & 3.14 & 1.47 \\
I talk to my family and friends with pride about my future hospitality career & 34.7 & 19.2 & 46.0 & 3.14 & 1.47 \\
\hline
\end{tabular}

Table 4: Students' Commitment to the Hospitality Industry

\begin{tabular}{lllllll}
\hline Statement & \multicolumn{7}{l}{ Pre-Internship } & Post-Internship & \\
Commitment to the Hospitality Industry & $\mathrm{M}$ & $\mathrm{SD}$ & $\mathrm{M}$ & $\mathrm{SD}$ & $\mathrm{Z}$ & $\mathrm{P}$ \\
\hline Disadvantages of working in the hospitality outweighs its advantages & 3.41 & 1.24 & 3.16 & 1.40 & -1.00 & .314 \\
I see myself working in the hospitality industry after graduation & 4.22 & 1.28 & 4.38 & 1.07 & -.220 & .826 \\
I do not plan to work in any other industry apart from the hospitality & 3.66 & 1.11 & 4.01 & .912 & -.131 & .896 \\
industry & & & & & & \\
I would only work in high paid jobs & 3.76 & 1.39 & 3.38 & 1.24 & -.825 & .409 \\
I would recommend hospitality jobs to friends and relatives & 4.04 & 1.18 & 4.28 & 1.13 & -.574 & .566 \\
It was a big mistake to choose hospitality as a career path & 2.04 & 1.15 & 2.17 & .912 & -.504 & .614 \\
I will work in the hospitality industry only if I made a supervisor on & 2.53 & 1.42 & 2.69 & 1.46 & -1.37 & .169 \\
graduation & & & & & & \\
It is definite I will not work in the hospitality industry after & 2.65 & 1.40 & 2.64 & 1.34 & -1.27 & .201 \\
graduation & & & & & & \\
I would do any job in the hospitality industry after graduation & 3.60 & 1.46 & 3.78 & 1.40 & -.115 & .909 \\
I would like to work in the hospitality industry after graduation & 3.91 & 1.22 & 4.05 & 1.12 & -.237 & .812 \\
I would not want my child to study or work in the hospitality & 2.71 & 1.22 & 2.81 & 1.50 & -.489 & .625 \\
industry & & & & & & \\
I am happy to have chosen hospitality & 4.10 & 1.52 & 4.34 & 1.50 & -.783 & .434 \\
\hline
\end{tabular}

\section{Nature of Hospitality Work, Industry-Person Congeniality, and Social Status}

With respect to the perception of the nature of hospitality work before and after internship experiences, mean perception regarding students finding jobs in the hospitality industry interesting appeared to have reduced significantly after their exposure to the industry (Table 5).
Also, there was a mean difference in students' perception regarding an aspect of their industry-person congeniality i.e. their likeness for customer service work marginally increased post internship $(\mathrm{p}=0.037)$. There was, however, no significant difference before and after the internship experiences of hospitality students on their perception of the social status of hospitality work. 
Table 5: Students Perception on Nature of Hospitality Work, Industry-Person Congeniality, and Social Status

\begin{tabular}{|c|c|c|c|c|c|c|}
\hline \multirow[t]{2}{*}{ Statement } & \multicolumn{2}{|c|}{ Pre-Internship } & \multicolumn{2}{|c|}{ Post-Internship } & \multirow{2}{*}{$\mathrm{Z}$} & \multirow[b]{2}{*}{$\mathrm{P}$} \\
\hline & M & SD & M & SD & & \\
\hline \multicolumn{7}{|l|}{ Nature of Hospitality Work } \\
\hline I find jobs in the hospitality industry interesting & 4.18 & 1.13 & 3.93 & 1.25 & -2.30 & .021 \\
\hline Most jobs in the hospitality industry are low skilled & 2.54 & 1.44 & 2.57 & 1.41 & -.589 & .556 \\
\hline Jobs in the hospitality industry are stressful & 3.68 & 1.27 & 3.54 & 1.31 & .000 & 1.000 \\
\hline Working hours are too long in the hospitality industry & 3.72 & 1.23 & 3.58 & 1.22 & -.107 & .915 \\
\hline Family life is negatively affected due to the nature of the hospitality work & 3.58 & 1.32 & 3.34 & 1.37 & -.659 & .510 \\
\hline There is always something new to learn each day in hospitality jobs & 4.07 & 1.12 & 4.44 & .882 & -.795 & .427 \\
\hline Working hours are not suitable for a regular life in the hospitality industry & 3.51 & 1.29 & 3.51 & 1.22 & .000 & 1.000 \\
\hline \multicolumn{7}{|l|}{ Industry-Person Congeniality } \\
\hline My character fits with the hospitality industry & 3.90 & 1.23 & 3.97 & 1.17 & -.581 & .561 \\
\hline I can use my skills and abilities in the hospitality industry & 4.05 & 1.21 & 4.02 & 1.19 & -.75 & .450 \\
\hline I feel like a maid servant working in the hospitality industry & 3.02 & 1.60 & 2.74 & 1.42 & .000 & 1.00 \\
\hline I get pleasure working in the hospitality industry & 3.96 & 1.11 & 4.02 & 1.16 & .000 & 1.00 \\
\hline I like to see satisfied customers & 4.23 & 1.07 & 4.15 & 1.11 & -.530 & .596 \\
\hline I like to serve others & 4.15 & 1.14 & 4.33 & 1.07 & -.756 & .450 \\
\hline I enjoy doing customer service work & 4.13 & 1.01 & 4.46 & .826 & -2.08 & .037 \\
\hline This hospitality field suits my ability & 4.27 & .948 & 4.48 & .726 & .000 & 1.00 \\
\hline \multicolumn{7}{|l|}{ Social Status } \\
\hline My family is proud of my future profession as a hospitality worker & 4.05 & 1.16 & 4.21 & 1.05 & -.875 & .382 \\
\hline Working as a hospitality staff is respected & 3.89 & 1.24 & 3.83 & 1.25 & -.949 & .342 \\
\hline I think that those working as hospitality staff are not valued & 3.16 & 1.48 & 3.11 & 1.47 & -1.00 & .314 \\
\hline $\begin{array}{l}\text { I talk to my relatives and friends with pride about my hospitality future } \\
\text { career }\end{array}$ & 3.97 & 1.26 & 4.09 & 1.14 & -.237 & .812 \\
\hline
\end{tabular}

\section{DISCUSSION AND CONCLUSION}

The hospitality industry is one of the most populated with employees and students alike studying and occupying both managerial and professional positions. Students at the undergraduate level remain a desirable source of workforce for the industry, and their future career intentions towards the industry are relevant to its success. As internships play a major role within the higher educational environment's control, potentially impacting students' perceptions and career aspirations (Wan et al., 2014), this study explores whether there is a change in students' perception of hospitality employment post internship and how this impacts on future career intentions from a developing country's perspective.

Kusluvan and Kusluvan (2000), Richardson (2008), as well as Roney and Tin (2007) maintained that, through exposure to the hospitality employment prior to graduation, student interns have the tendency to express disinterest in their commitment to the industry post-graduation. Results of this study seem to suggest that, rather on the contrary, students indicated a commendable commitment towards the hospitality industry before and after their internship work experiences. Also, students did not regret their decisions to study hospitality and indicated their happiness to have chosen hospitality as a programme of study, as opposed to students from Australia reporting that it was a big mistake for them to have chosen hospitality as a career path (Richardson, 2010). Largely, the students in this study were committed to the hospitality industry, and they expressed their intention to work in the sector after graduation and even recommend hospitality jobs to friends (Table 1).

Similar to results reported in some earlier hospitality student studies (Bury \& Iwasaki, 2018; Richardson, 2010), the nature of 
hospitality work clearly indicates that students perceived hospitality industry workplaces to be stressful and characterized by long working hours that negatively affect family life and making attainment of regular life difficult (Table 2). These perceptions held by the students in the current study are similar to those expressed in earlier studies involving hospitality worker samples (Hodari, Waldthausen, \& Sturman, 2014; Jung \& Yoon, 2013; Mohamed, 2015). In line with an earlier conception of the hospitality industry as being a stressful work place (Kim, Shin, \& Umbreit, 2007; Wildes, 2007), students in the current study accurately perceived hospitality work to be stressful (Table 2). This finding is an indication that the students had a deeper understanding and knowledge of the hospitality industry.

In investigating the social status dimension of the hospitality work, it was found that students perceived their families and friends supportive to their future profession in the hospitality industry, as they indicated being proud discussing their profession in the hospitality industry with their families and friends (Table 3). Given the important role of family and friends in career motivation and long-term commitment to chosen professions (Carless, 2005; Wong \& Liu, 2010; Wu, 2013), the findings of the current study indicated that students will discuss, with pride, their interest in hospitality and tourism career, particularly in an era where most hospitality graduates have been found to show much disinterest in hospitality and tourism career. The social support from family and friends is important when working in the hospitality industry because of the job characteristics of long and irregular working hours and the possibility of work-family conflict. The social support from family and friends would be an important resource in coping with the stressful nature of hospitality work.

Industry-person congeniality is very important, as it has been found to be related to several work place outcomes such as performance (Youshan \& Hassan, 2015), job satisfaction (Farooqui \& Nagendra, 2014; Mete, Sökmen, \& B1y1k, 2016), organizational commitment (Mete, Sökmen, \& Biy1k, 2016), and turnover intentions (Memon, Salleh, Baharom, \& Harun, 2014). The current study investigated students' perceived industryperson congeniality and results of the study showed that students perceived their personality to be in congruence with hospitality work because their character fits the hospitality and tourism industry, as the sector provides them the opportunity to use their skills and abilities (Table 3). Furthermore, based on the results of the study, the students appeared to indicate a predisposition to customer orientation. These traits are critical to a successful career in the hospitality industry, as employees with predisposition to customer orientation are likely to deliver quality service.

The study concludes with one interesting and important finding from the Wilcoxon rank tests that exposure to hospitality industry does not significantly alter students' commitment to the hospitality industry, their perception of the nature of hospitality work, industry-person congeniality, and perceived social status of hospitality career (Table 4), as previously perceived in earlier studies (Kim \& Park, 2013; Richardson, 2009). This conclusion is in contrast with earlier studies that have suggested that internship experiences of the hospitality industry trigger negative attitudes among hospitality and tourism students (Kusluvan \& Kusluvan, 2000; Richardson, 2008; Roney \& Tin, 2007) but it is in line with others that have concluded that participation in hospitality industry internship had an overall significant and positive effect on students (Bury \& Iwasaki, 2018; Lu \& Adler, 2009).

\section{Implications of the Study}

The findings of this study establish the need to critically research the perceptions of students towards careers in specific sectors of the hospitality industry and further from the developing country's perspective due to difference in the level of development, educational standards, dependency on the hospitality and tourism industry, as well as cultural differences. While the results of this study cannot be generalized across all undergraduate hospitality students, the study provides some useful information relevant to the universities around the world that teach hospitality and tourism management. Since the positive and negative experiences of the internship programme could motivate student to join the industry and have career maturity as well as decrease the motivation to join the same industry, management of internship programmes should continuously monitor intern performance to make sure students are benefiting, regularly check their internship program, and review the 
activity to increase the usefulness of internship the program.

\section{Limitations}

As with other studies, this study is not without limitations. First of all, the sample size employed in this study is modest and limited to students from a Ghanaian technical university. Also, since the internship programme is of different structures and duration across educational disciplines, care should be taken when generalizing the findings of this study in different contexts. For further studies, it is suggested that samples selected should be

\section{REFERENCES}

Aksu, A. A., \& Koksal, C. D. (2005). Perceptions and attitudes of tourism students in Turkey. International Journal of Contemporary Hospitality Management, 17, 436-447.

Aloudat, A. S. (2017). Undergraduate students' perceptions of a tour guiding career. Scandinavian Journal of Hospitality and Tourism, 17(4), 333-344.

Atadero, R. A., Rambo-Hernandez, K. E., \& Balgopal, M. M. (2015). Using social cognitive career theory to assess student outcomes of group design projects in statics. Journal of Engineering Education, 4(1), 55-73. doi: 10.1002/ jee. 20063 .

Australian Bureau of Statistics. (2006). Australian labour market statistics (No. 6105.0). Canberra, Australia.

Ayres, H. (2006). Education and opportunity as influences on career development: Findings from a preliminary study in eastern Australian tourism. Journal of Hospitality, Leisure, Sport and Tourism Education, 5(1), 16-27.

Brien, A. (2004). Do I want a job in hospitality? Only till I get a real job! In K. A. Smith \& C. Schott (Eds.), Proceedings of the New Zealand tourism and hospitality research conference, pp. 35-42. Wellington, New Zealand.

Brown, E. A., Arendt, S. W., \& Bosselman, R. H. (2014). Hospitality management graduates' perceptions of career factor importance and career factor experience. International Journal of Hospitality Management, 37, 58-67. students whose major is either tourism or hospitality and not a combination of the two, in order to fully explore the effects of a student's study major on his/her career aspirations after undertaking an internship, and being attentive to matching majors with sectors to more accurately determine aspirations related to the context of his/her studies. In this current research, the student participants were studying hospitality and tourism management as a major. Future studies should also distinguish between hospitality-specific internships and tourism-specific internships to examine fully the influence of the industry context.

Busby, G. (2003). Tourism degree internship: A longitudinal study. Journal of Vocational Education and Training, 55(3), 319-344.

Chang, S., \& Tse, E. C.-Y. (2015). Understanding the initial career decisions of hospitality graduates in Hong Kong: Quantitative and qualitative evidence. Journal of Hospitality and Tourism Research, 39(1), 57-74.

Chen, T. L. \& Shen, C. C. (2012). Today's intern, tomorrow's practitioner? The influence of internship programmes on students' career development in the hospitality industry. Journal of Hospitality, Leisure, Sport, and Tourism Education, 11(1), 29-40.

Cho, M. (2006). Student perspectives on the quality of hotel internships. Journal of Teaching in Travel and Tourism, 6(1), 61-76.

Davidson, M. C. G., Timo, N., \& Wang, Y. (2010). How much does labour turnover cost? A case study of Australian fourand five-star hotels. International Journal of Contemporary Hospitality Management, 22(4), 451-466.

Doherty, L., Guerrier, Y., Jamieson, S., Lashley, C., \& Lockwood, A. (2001). Getting ahead: Graduate careers in hospitality management. London: Council for Hospitality Management Education/ Higher Education Funding Council for England.

Farooqui, S., \& Nagendra, A. (2014). The impact of person organization fit on job satisfaction and performance of the Employees. Procedia Economics and Finance, 11, 122 -12.

Ghobadian, A. Speller, S., \& Jones, J. (1994). 
Service quality: Concepts and models. International Journal of Quality \& Reliability Management, 11(9), 43-66.

Hodari, D., Waldthausen, V., \& Sturman, M. (2014). Outsourcing and role stress: An empirical study of hotel spa managers. International Journal of Hospitality Management, 37, 190-199.

Horng, J. S. (2004). Curriculum analysis of foods and beverage management of technological and vocational education in Taiwan. Asia Pacific Journal of Tourism Research, 9(2), 107-119.

Horng, J., \& Lee, M. (2005). Tourism and hospitality higher education in Taiwan: past, present and future. Journal of Teaching in Travel and Tourism, 5(3), 167-169.

Jenkins, A. K. (2001). Making a career of it? Hospitality students' future perspectives: An Anglo-Dutch study. International Journal of Contemporary Hospitality Management, 13, 13-20.

Jiang, B. \& Tribe, J. (2009). Tourism jobs - short lived professions: students' attitude towards tourism careers in China. Journal of Hospitality, Leisure, Sport \& Tourism Education, 8(1), 4-19.

Jung, H. S. \& Yoon, H. H. (2013). Is the individual or the organization the cause of hotel employees' stress? A longitudinal study on differences in role stress between subjects. International Journal of Hospitality Management, 33, 494-499.

Kim, H. B., \& Park. E. J. (2013). The role of social experience in undergraduates' career perceptions through internship. Journal of Hospitality, Leisure, Sports and Tourism Education. 12(1), 70-78.

Koc, E., Yumusak, S., Ulukoy, M., Kilic, R., \& Topas, A. (2015). Are internship programmes encouraging or discouraging? A viewpoint of hospitality and tourism students in Turkey. Journal of Hospitality, Leisure, Sport and Tourism Education, 15, 135-142.

Kusluvan, S., \& Kusluvan, Z. (2000). Perceptions and attitudes of undergraduate tourism students towards working in the tourism industry in Turkey. Tourism Management, 21(3), 251-269.

Lam, T., \& Ching, L. (2007). An exploratory study of an internship program: The case of Hong Kong students. International Journal of Hospitality Management, 26, 336-351.

Lee, C. S., \& Chao, C. W. (2013). Intention to 'leave' or 'stay' - the role of internship organization in the improvement of hospitality students' industry employment intentions. Asia Pacific Journal of Tourism Research, 18(7), 749-765.

Lee, C. S. \& Chao, J. W. (2008). A study on the school-outside internship programme of hospitality department in Taiwan. Journal of Hospitality and Home Economics, 5(3), 247-272.

Lent, R. W., \& Brown, S. D. (2008). Social cognitive career theory and subjective well-being in the context of work. Journal of Career Assessment, 16(1), 6-21. doi:10.1177/1069072707305769.

Lent, R. W., Brown, S. D., \& Hackett, G. (1994). Toward a unifying social cognitive theory of career and academic interest, choice, and performance [Monograph]. Journal of Vocational Behavior, 45, 79122.

Lent, R. W., Brown, S. D., \& Hackett, G. (1996). Career development from a social cognitive perspective. In D. Brown, L.

Lent, R. W., Brown, S. D., Schmidt, J., Brenner, B., Lyons, H., \& Treistman, D. (2003), "Relation of contextual supports and barriers to choice behavior in engineering majors: Test of alternative social cognitive models", Journal of Counseling Psychology, 50(4), pp. 458465. doi:10.1037/0022-0167.50.4.458.

Lent, R., Brown, S., \& Hackett, G. (2000), "Contextual supports and barriers to career choice: A social cognitive analysis", Journal of Counseling Psychology, 47(1), pp. 36-49. doi: http://dx.doi.org/10.1037/00220167.47.1.36.

Leslie, D., \& Richardson, A. (2000). Tourism and cooperative education in the UK undergraduate courses: Are the benefits being realized? Tourism Management, 21, 489-498.

Lu, T., \& Adler, H. (2009) 'Career Goals and Expectations of Hospitality and Tourism Students in China', Journal of Teaching 
in Travel \& Tourism, 9(1-2), 63-80.

Marinakou, E., \& Giousmpsoglou, C. (2013). An Investigation of Student Satisfaction from Hospitality Internship Programs in Greece. Journal of Tourism and Hospitality Management, 1(3), 103-112.

Memon, M. A., Salleh, R., Baharom, M. N. R., \& Harun, H. (2014). PersonOrganization Fit and Turnover Intention: The Mediating Role of Employee Engagement. Global Business and Management Research: An International Journal, 6(3), 205-209.

Mete, E. S., Sökmen, A., \& Biyık, Y. (2016). The Relationship between Organizational Commitment, Organizational Identification, Person-Organization Fit and Job Satisfaction: A Research on IT Employees. International Review of Management and Business Research, 5(3), 870-901.

Mohamed, L. M. (2015). An exploratory study on the perceived work stress by individual characteristics: The case of Egyptian hotels. Journal of Hospitality and Tourism Management, 25, 11-18.

Mueller, C. E., Hall, A. L., \& Miro, D. Z. (2015), "Testing an Adapted Model of Social Cognitive Career Theory: Findings and Implications for a self-selected, diverse middle-school sample", Journal of Research in STEM Education, 1(2), pp. 142-155.

Ng, E. S. W., \& Burke, R. K. (2006). The next generation at work - business students' views, values and job search strategy: Implications for universities and employers. Education and Training, 48(7), 478-492.

O’Mahony, G. B., \& Sillitoe, J. F. (2001). Identifying the perceived barriers of participation in tertiary education among hospitality employees. International Journal of Contemporary Hospitality Management, 13(1), 21-9.

Park, S. A., Kim, H., \& Lee, K. (2017). Perceptions of determinants of job selection in the hospitality and tourism industry: The case of Korean university students. Journal of Human Resources in Hospitality \& Tourism, 16(4), 422-444.

Pavesic, D. V., \& Brymer, R. A. (1990). Job satisfaction: What's happening to the young managers. Cornell Hotel and Restaurant Administration Quarterly, 31(1), 90-96.

Penny, W. Y., \& Frances K. W. (2011). Career perceptions of undergraduate gaming management students'. Journal of Teaching in Travel and Tourism, 11(4), 367-391.

Poulston, J. (2008). Hospitality workplace problems and poor training: A close relationship. International Journal of Contemporary Hospitality Management, 20(4), 412-427.

Raybould, M., \& Wilkins, H. (2005). Over qualified and under experienced. International Journal of Contemporary Hospitality Management, 17(3), 203-216.

Richard, N. S., Ruhanen, R. L., \& Breakey, N. M. (2016). Tourism and hospitality internships: Influences on student career aspirations. Current Issues in Tourism, 19(6), 513-527.

Richardson, S. (2009). Undergraduates' perceptions of tourism and hospitality as a career choice. International Journal of Hospitality Management, 28(3), 382388.

Richardson, S. (2010). Undergraduate tourism and hospitality students' attitudes toward a career in the industry: A preliminary investigation. Journal of Teaching in Travel \& Tourism, 8(1), 23-46.

Richardson, S. (2012). Utilizing generation Y: United States hospitality and tourism students' perceptions of careers the industry. Journal of Hospitality and Tourism Management, 19(1), 102-114.

Riley, M., Ladkin, A., \& Szivas, E. (2002). Tourism employment: Analysis and planning. Sydney: Channel View.

Roney, S. A., \& Öztin, P. (2007). Career perceptions of undergraduate tourism students: A case study in Turkey. Journal of Hospitality, Leisure, Sport, \& Tourism Education, 6(1), 4-18.

Ruhanen, L., Robinson, R., \& Breakey, N. (2013). A tourism immersion internship: Students' expectation, experiences and satisfaction. Journal of Hospitality, Leisure, Sport \& Tourism Education, 13, 60-90.

Sabirin, A. S., Munawaroh, \& Are, R. L. (2018). Is internship program impact career 
development perception? Empirical study on "SGU" hospitality students. Advances in Economics, Business and Management Research, 52, 95-109.

Seyitoğlu, F. \& Yirik, S. (2015). Internship satisfaction of students of hospitality and impact of internship on the professional development and industrial perception. Asia Pacific Journal of Tourism Research, 20(1), 1414-1429.

Soliman, D. M. (2011). Entrepreneurial intention among tourism undergraduate students in Egypt. Tourism Analysis, 16(4), 471-481.

Tse, T. (2010). What do hospitality students find important about internships? Journal of Teaching in Travel \& Tourism, 10(3), 251-264.

Wan, Y. K., Wong, I. A., \& Kong, W. H. (2014). Student career prospect and industry commitment: The roles of industry attitude, perceived social status, and salary expectations. Tourism Management, 40, 1-14.

Wong, S. C. K. \& Liu, G. J. (2010). Will parental influences affect career choice? Evidence from hospitality and tourism management students in China. International Journal of Contemporary Hospitality Management, 22(1), 82-102.

World Travel and Tourism Council (WTTC). (2017). Travel and tourism economic impact Caribbean. London: World Travel and Tourism Council. Retrieved from https://www.wttc.org/-/media/files/ reports/economic-impact-research/ regions-2017/caribbean2017.pdf

Wu, M. Y. (2013). "I would love to work in tourism, but..." Exploring the outcomes of an ethnic tourism education initiative. Journal of Hospitality, Leisure, Sport \& Tourism Education, 12(1), 47-58.
Wu, S. C. \& Wu, W. C. (2006). The research of interns' job performance and job satisfaction in the tourism industry. Journal of Hospitality and Home Economics, 3(4), 473-491.

Xinyuan, R. Z. \& Ghiselli, R. (2016). Why do you feel stressed in a "smile factory"? International Journal of Contemporary Hospitality Management, 28 (2), 305326.

Yang, O. H. \& Cherry, N. (2008). Human resource management challenges in the hotel industry in Taiwan. Asia Pacific Journal of Tourism Research, 13(4), 399-410.

Youshan, B. B. \& Hassan, Z. (2015). The effect of employees' personality on organizational performance: Study on insurance company. International Journal of Accounting \& Business Management, 3(1), 187-196.

Zacerelli, H. E. (1985). Is the hospitality-food service industry turning its employees on-or off? The manager makes the decision. International Journal of Hospitality Management, 4, 123-124.

Zopiatis, A. (2007). Hospitality internships in Cyprus: A genuine academic experience or a continuing frustration? International Journal of Contemporary Hospitality Management, 19(1), 65-77.

Zopiatis, A., \& Theocharous, A. (2013). Revisiting hospitality internship practices: A holistic Investigation. Journal of Hospitality, Leisure, Sport \& Tourism Education, 13, 33-46. 